\title{
27. DATA REPORT: GRAIN-SIZE ANALYSIS OF SEDIMENTS FROM THE NORTHERN BARBADOS ACCRETIONARY PRISM ${ }^{1}$
}

\author{
Audrey Meyer ${ }^{2}$ and Andy Fisher ${ }^{3}$
}

\section{INTRODUCTION}

Ocean Drilling Program (ODP) Leg 156 examined hydrological, geochemical, structural, and sedimentological processes at the toe of the northern Barbados accretionary prism (Shipley, Ogawa, Blum, et al., 1995). As part of this program, more than 400 samples were collected from Sites 948 and 949 for grain-size analysis. The primary objective of these analyses was to accurately determine weight percentages of sand, silt, and clay, to provide textural information that could be correlated with other types of data analyses made on immediately adjacent samples.

The sediments collected during Leg 156 were dominantly finegrained clays and silts, with minor sands in lithologic Unit III below the décollement (Shipley, Ogawa, Blum, et al., 1995). In this study, we used the well-established size boundaries of $63 \mu \mathrm{m}$ separating sand and silt, and $4 \mu \mathrm{m}$ separating silt and clay.

\section{METHODS}

\section{Sampling Strategy}

Samples used in this study comprised $20-25 \mathrm{~cm}^{3}(40-50 \mathrm{~g})$ of wet sediment, collected at a frequency of approximately one per section throughout Sites 948 and 949. Sample locations were chosen immediately adjacent to other samples collected for water content, porosity, bulk density, bulk X-ray diffraction, carbonate, and total carbon studies, to allow correlation between data sets. In addition, $~ 40$ samples were trimmed from whole-round sections of the cores that were collected for shore-based laboratory mechanical and hydrological testing.

Samples collected for this study were divided into two sets, alternating downhole at each site. One sample set was analyzed with the pipette method, and the other analyzed on a SediGraph, as described below. A selected set of samples was analyzed by both methods to intercalibrate the two datasets.

\section{Sample Preparation and Sand Content Analysis}

Samples in both sample sets were placed in a freezer for approximately $24 \mathrm{hr}$ to facilitate the freeze-drying process, and then freezedried to remove intergranular moisture. Dried samples were temporarily placed in a desiccator to avoid rehydrating while preparing for analysis.

Approximately $15-20 \mathrm{~g}$ of sample were weighed into a $600-\mathrm{ml}$ pyrex beaker. A $100-\mathrm{ml}$ aliquot of $30 \%$ hydrogen peroxide and a $400-$ $\mathrm{ml}$ aliquot of freshly prepared $4 \mathrm{~g}$ sodium hexametaphosphate/L dis-

${ }^{1}$ Shipley, T.H., Ogawa, Y., Blum, P., and Bahr, J.M. (Eds.), 1997. Proc. ODP, Sci. Results, 156: College Station, TX (Ocean Drilling Program).

${ }^{2}$ Sea Education Association, Woods Hole, MA 02543, U.S.A. audreym@ @ sea.edu

Department of Earth Sciences, University of California at Santa Cruz, Santa Cruz, CA 95064, U.S.A. persant solution were added to the beaker. Digestion was allowed to continue for at least $12 \mathrm{hr}$.

The sand fraction was separated from the silt and clay fractions by wet sieving the disaggregated sample through a $63-\mu \mathrm{m}$ sieve. The sand fraction remained in the sieve; silt and clay were washed through the sieve into a 1-L beaker. The sand fraction was then rinsed with distilled water, transferred onto a pre-weighed petri dish, and placed into a $70^{\circ} \mathrm{C}$ oven. When dry, the petri dish was reweighed, and the total weight of the dish and sand recorded. The total mass of the sand was calculated by relative comparison with the initial weight of the sample.

\section{Sample Analysis—SediGraph Technique}

The wash solution containing the silt and clay fractions of the sample was placed on a heated stirrer and allowed to stir for approximately 10 min until the sample was completely homogeneous. Aliquots of this solution were then transferred into two 50-ml "Falcon" centrifuge tubes. The samples were then centrifuged at $8000 \mathrm{rpm}$ for $20 \mathrm{~min}$, the excess liquid was poured off, and $\sim 20 \mathrm{ml}$ of fresh dispersant solution was added to each centrifuge tube. The centrifuge tubes were placed in a sonicator until the sediment was dispersed enough to transfer completely to a $90-\mathrm{ml}$ Wheaton jar.

Grain-size analyses were conducted on the Micromeritics SediGraph Model 5000 at Scripps Institution of Oceanography. The SediGraph technique is described in detail in Coakley and Syvitski (1991); further discussions of the operations of the instrument are provided in Hendrix and Orr (1972), Stein (1985), and Jones et al. (1988). The SediGraph method assumes that particles are dispersed in a fluid and settle according to Stoke's Law. The SediGraph uses a collimated beam of X-rays to sense changing concentration of the sediments settling in a suspension as a function of time, and uses that information to determine the size distribution of the settling particles. The data are presented as a cumulative-mass percent distribution in terms of equivalent spherical diameter. No specific sediment concentration is required for the analysis, providing the dispersed sample reduces the radiation beam by $40 \%-60 \%$. The technique is valid for silt- and claysize particles, and samples containing clay-size material pose the greatest analytical problems because of light dispersion, influence of fluid viscosity, and particle-particle interaction (Singer et al., 1988).

Each day, a fresh solution of $1 \mathrm{~g}$ sodium hexametaphosphate/L solution was prepared and used to determine the baseline of the SediGraph. Before analysis, each sample was agitated in its Wheaton jar to ensure homogeneity, immediately before being transferred to the SediGraph.

The program utilized on the SediGraph had a starting diameter of $64 \mu \mathrm{m}$ and an ending diameter of $1 \mu \mathrm{m}$. Size divisions measured included: > $64 \mu \mathrm{m}, 64-32 \mu \mathrm{m}, 32-16 \mu \mathrm{m}, 16-8 \mu \mathrm{m}, 8-4 \mu \mathrm{m}, 4-2 \mu \mathrm{m}$, and $2-1 \mu \mathrm{m}$. As a total weight sedimentation method, the instrument yielded the percentages finer than the lowest analysis point. When the program produced results showing that less than $50 \%$ of the sample fell into the measured grain-size range (i.e., that more than $50 \%$ of the sample was less than $1 \mu \mathrm{m}$ diameter), a number of samples were re- 
run on a $64 \mu \mathrm{m}$ to $0.18 \mu \mathrm{m}$ scale (which included divisions for $1-0.5$ $\mu \mathrm{ms}, 0.5-0.25 \mu \mathrm{m}$, and $0.25-0.18 \mu \mathrm{m})$ to insure correct operation of the SediGraph. It was found that these samples indeed contained particles less than $1 \mu \mathrm{m}$ in size.

Data produced automatically from the SediGraph (i.e., cumulative-mass percent distributions in terms of equivalent spherical diameter) had to be converted into relative percentages of silt and clay. To do this, the absolute percentage of silt + clay was first determined by subtracting the sand weight percentage (determined as described above) from $100 \%$. Clay and silt weight percentages were determined by apportioning their cumulative-mass percent distributions to their total absolute percentage.

Studies have shown that the SediGraph technique overestimates clay percentages, especially in samples with high clay content. This is caused by increased particle-particle interaction (Stein, 1985), and particle-shape effects on settling velocities because the SediGraph assumes spherical particles (M. Kastner, pers. comm., 1995). Kastner has compared grain-size data determined by centrifuge techniques vs. SediGraph techniques for samples from the California Margin. Using these comparative analyses, she has constructed a calibration curve that allows correction of clay percentages determined by SediGraph analysis (M. Kastner, pers. comm., 1995). True clay weight percentages were thus determined by:

$$
\mathrm{Y}=1.11 \mathrm{X}-15.03
$$

where $\mathrm{X}$ is the clay percentage as measured on the SediGraph, and $\mathrm{Y}$ is the corrected clay content. We applied these correction factors to our SediGraph data. While the correction factor determined on California Margin samples may not be exactly applicable to our Barbados Margin samples, it is probably not off by more than about $2 \%$.

To ensure data reliability, both standards and duplicate and triplicate samples were run. Data reproducibility was generally $\pm 5 \%$.

\section{Sample Analysis-Pipette Method}

The pipette method used to determine grain size of the second sample set was adapted from Folk (1974). We anticipated that there would be some discrepancy between the two data sets, because of the different analysis methods used. However, based on earlier comparative studies of SediGraph and pipette analyses (Welch et al., 1979), we believed our data sets would prove comparable. Indeed, early calibration of a small selected set of our samples indicated that this was true; however, this was not ultimately the case. Grain-size analyses determined by the pipette method showed significantly lower data reproducibility, and considerable data scatter within relatively homogeneous sediment sections. Thus, we have opted not to include the pipette data in this report.

\section{RESULTS}

Sand, silt, and clay percentages determined by SediGraph analysis are given in Table 1 (Site 948) and Table 2 (Site 949). Data from lithologic Units II and III are plotted in Figure 1 (Site 948) and Figure 2 (Site 949). Data from lithologic Unit I (mudline cores only) are not plotted. The data are available from the ODP Database Group in electronic format.

Lithologic Unit I consists of unconsolidated clay with nannofossils and foraminifers and minor amounts of volcanic ash (Shipley,
Ogawa, Blum, et al., 1995). Sand, silt, and clay data reflect the varying amounts of these biologic and volcanogenic components. Sand contents range from $3 \%$ to $32 \%$, silt content ranges from $12 \%$ to $46 \%$, and clay content ranges from $40 \%$ to $83 \%$; averages are $13 \%, 21 \%$, and $66 \%$, respectively.

Lithologic Unit II consists of homogeneous, hemipelagic claystone with intervals including nannofossils or radiolarians, which allowed us to divide the section into six subunits (Subunits IIa-IIf; Fig. 1). As expected from core descriptions and smear-slide analyses completed on board, these sediments are consistently fine grained throughout. Clay contents range from $72 \%$ to $95 \%$, and silt contents range from $1 \%$ to $26 \%$. Only minor amounts of sand occur in these samples, ranging from $0 \%$ to $8 \%$, but averaging only $2 \%$.

The sediments in lithologic Unit III, below the décollement, are not homogeneous. They include variegated claystone interbedded with graded and laminated siltstone, greenish gray clayey siltstone, and gray claystone with nannofossils. The heterogeneous nature of this sediment section is reflected in the grain-size data. Sand content is low (range $=0 \%-21 \%$; average $=2 \%$ ), as most of the "coarse" layers in this unit do not contain material coarser than silt. Silt content ranges from $1 \%$ to $51 \%$, and even the "siltstone" layers contain significant amounts of clay material.

\section{ACKNOWLEDGEMENTS}

The SediGraph at Scripps Institution of Oceanography was kindly made available to us by Lisa Levin. SediGraph samples were analyzed and data were reduced with the assistance of Tamara Davis and Bill Meyer. This study was supported by United States Science Support Program (USSSP) grants provided to both authors and Miriam Kastner.

\section{REFERENCES}

Coakley, J.P., and Syvitski, J.P.M., 1991. SediGraph technique. In Syvitski, J.P.M. (Ed.), Principles, Methods, and Application of Particle Size Analysis: (Cambridge Univ. Press), 129-142.

Folk, R.L., 1974. Petrology of Sedimentary Rocks: Austin, Texas (Hemphill Publ. Co.).

Hendrix, W.P., and Orr, C., 1972. Automatic sedimentation size analysis instrument. In Groves, M.J., and Wyatt-Sargent, J.L. (Eds.), Particle Size Analysis 1970: London (Soc. Analytical Chem.), 133-146.

Jones, K.P.N., McCave, I.N., and Patel, P.D., 1988. A computer-interfaced SediGraph for modal analysis of fine-grained sediment. Sedimentology, 35: $163-172$

Shipley, T.H., Ogawa, Y., Blum, P., et al., 1995. Proc. ODP, Init. Repts., 156: College Station, TX (Ocean Drilling Program).

Singer, J.K., Anderson, J.B., Ledbetter, M.T., McCave, I.N., Jones, K.P.N., and Wright, R., 1988. An assessment of analytical techniques for the size analysis of fine-grained sediments. Jour. Sed. Petrol., 58: 534-543.

Stein, R., 1985. Rapid grain-size analyses of clay and silt fractions by SediGraph 5000D: comparison with Coulter Counter and Atterberg methods. Jour. Sed. Petrol., 55: 590-593.

Welch, N.H., Allen, P.B., and Galindo, D.J., 1979. Particle-size analysis by pipette and SediGraph. Jour. Environ. Qual., 8: 543-546.

Date of initial receipt: 6 February1996

Date of acceptance: 18 July 1996

Ms 156SR-005 
Table 1. Site 948 textural data

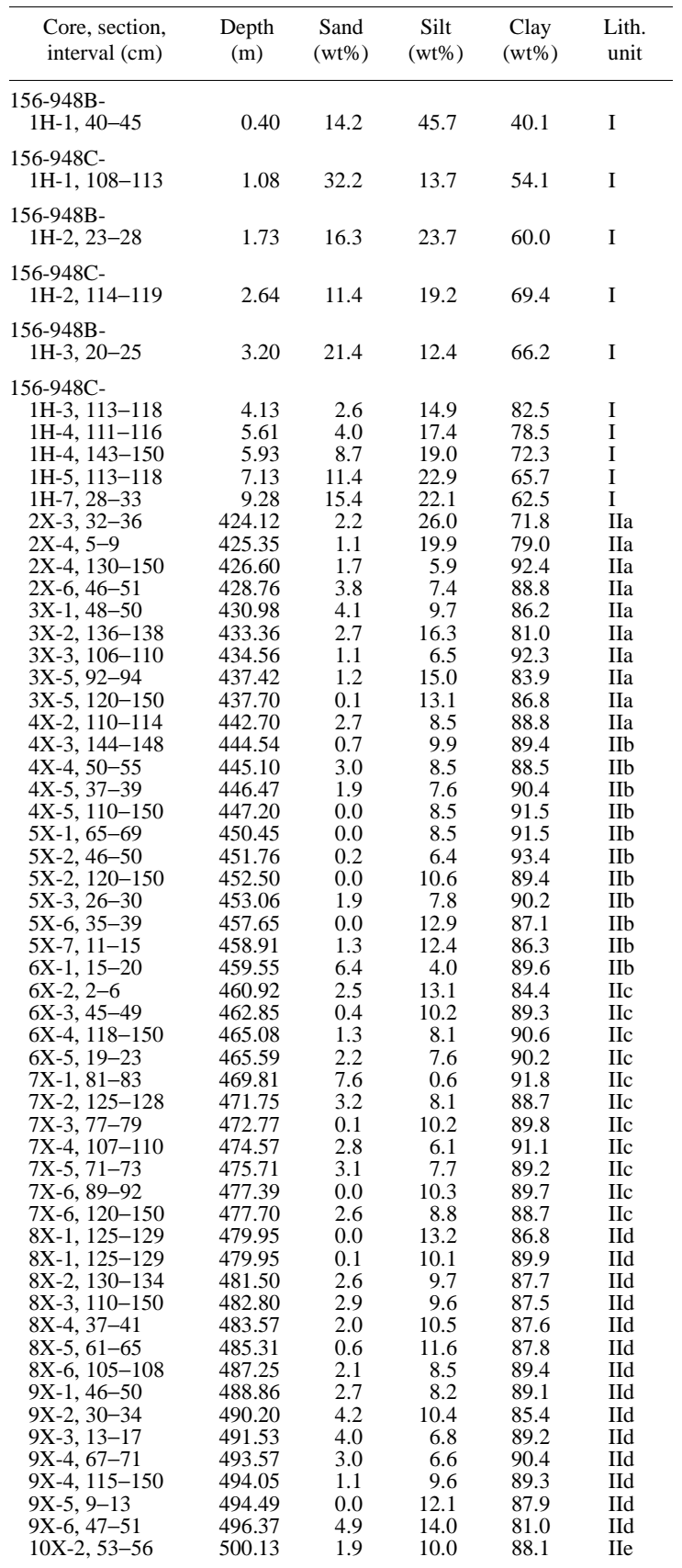

\begin{tabular}{|c|c|c|c|c|c|}
\hline $\begin{array}{l}\text { Core, section, } \\
\text { interval }(\mathrm{cm})\end{array}$ & $\begin{array}{l}\text { Depth } \\
\text { (m) }\end{array}$ & $\begin{array}{l}\text { Sand } \\
\text { (wt\%) }\end{array}$ & $\begin{array}{c}\text { Silt } \\
\text { (wt } \%)\end{array}$ & $\begin{array}{l}\text { Clay } \\
\text { (wt\%) }\end{array}$ & $\begin{array}{l}\text { Lith. } \\
\text { unit }\end{array}$ \\
\hline $10 X-3,15-19$ & 501.25 & 1.9 & 10.6 & 87.5 & IIe \\
\hline $10 X-3,110-150$ & 502.20 & 4.2 & 6.7 & 89.1 & IIe \\
\hline $10 X-5,12.0-16$ & 504.22 & 0.7 & 11.0 & 88.4 & IIe \\
\hline $10 \mathrm{X}-\mathrm{CC}, 19-23$ & 505.22 & 1.6 & 12.5 & 85.9 & IIe \\
\hline $11 X-1,72-76$ & 508.42 & 5.8 & 6.1 & 88.0 & IIf \\
\hline $11 X-2,29-33$ & 509.49 & 0.0 & 8.1 & 91.9 & IIf \\
\hline $11 X-3,13-17$ & 510.83 & 3.8 & 6.6 & 89.6 & IIf \\
\hline $11 X-4,39-43$ & 512.59 & 2.8 & 4.9 & 92.2 & IIf \\
\hline $11 X-4,110-150$ & 513.30 & 0.2 & 5.3 & 94.5 & IIf \\
\hline $11 X-5,9-13$ & 513.79 & 0.6 & 12.4 & 87.0 & IIf \\
\hline $12 X-1,74-78$ & 518.14 & 3.6 & 7.0 & 89.4 & IIIa \\
\hline $12 X-2,96-99$ & 519.86 & 0.0 & 7.5 & 92.5 & IIIa \\
\hline $12 X-4,78-82$ & 522.68 & 0.0 & 6.5 & 93.5 & IIIa \\
\hline $12 X-4,110-150$ & 523.00 & 0.0 & 6.5 & 93.5 & IIIa \\
\hline $13 \mathrm{X}-1,20-23$ & 527.00 & 0.0 & 28.8 & 71.2 & IIIb \\
\hline $13 \mathrm{X}-2,97-100$ & 529.27 & 0.0 & 5.5 & 94.5 & IIIb \\
\hline $13 \mathrm{X}-3,126-129$ & 531.06 & 0.2 & 7.5 & 92.3 & $\mathrm{IIIb}$ \\
\hline $13 X-4,76-79$ & 532.06 & 2.3 & 23.0 & 74.8 & IIIb \\
\hline $13 X-4,115-150$ & 532.45 & 0.8 & 7.3 & 91.9 & IIIb \\
\hline $13 \mathrm{X}-5,95-98$ & 533.75 & 1.1 & 6.9 & 92.0 & IIIb \\
\hline $13 X-6,88-91$ & 535.18 & 0.0 & 7.1 & 92.9 & IIIb \\
\hline $13 X-6,88-91$ & 535.18 & 0.5 & 5.9 & 93.5 & $\mathrm{IIIb}$ \\
\hline $14 X-1,38-41$ & 536.48 & 0.0 & 7.9 & 92.1 & IIIb \\
\hline $14 X-2,45-49$ & 538.05 & 0.0 & 13.8 & 86.2 & IIIb \\
\hline $14 X-3,12-16$ & 539.22 & 1.0 & 4.4 & 94.6 & $\mathrm{IIIb}$ \\
\hline $14 \mathrm{X}-4,22-26$ & 540.82 & 0.9 & 3.4 & 95.7 & IIIb \\
\hline $14 X-5,57-61$ & 542.67 & 4.5 & 8.0 & 87.5 & IIIb \\
\hline $14 X-5,120-150$ & 543.30 & 3.5 & 9.2 & 87.3 & IIIb \\
\hline $14 X-5,120-150$ & 543.30 & 1.0 & 9.0 & 90.0 & IIIb \\
\hline $14 \mathrm{X}-\mathrm{CC}, 6-10$ & 545.16 & 2.6 & 4.1 & 93.3 & IIIb \\
\hline $15 X-1,102-106$ & 546.42 & 0.8 & 4.6 & 94.6 & IIIb \\
\hline $15 X-3,0-2$ & 548.40 & 2.6 & 2.6 & 94.8 & IIIb \\
\hline $15 X-3,80-84$ & 549.20 & 1.5 & 4.8 & 93.7 & IIIb \\
\hline $15 X-4,123-127$ & 551.13 & 0.0 & 9.0 & 91.0 & IIIb \\
\hline $15 X-5,107-111$ & 552.47 & 0.1 & 8.0 & 91.9 & IIIb \\
\hline $15 X-6,110-150$ & 554.00 & 0.0 & 11.6 & 88.4 & IIIb \\
\hline $15 X-6,110-150$ & 554.00 & 0.0 & 12.4 & 87.6 & IIIb \\
\hline $15 X-6,110-150$ & 554.00 & 0.0 & 11.6 & 88.4 & $\mathrm{IIIb}$ \\
\hline $16 X-2,18-23$ & 556.48 & 0.2 & 26.0 & 73.8 & IIIb \\
\hline $16 \mathrm{X}-2,110-150$ & 557.40 & 3.6 & 0.8 & 95.6 & IIIb \\
\hline $16 X-3,32-37$ & 558.12 & 2.7 & 7.7 & 89.6 & $\mathrm{IIIb}$ \\
\hline $16 \mathrm{X}-4,18-22$ & 559.48 & 0.7 & 2.9 & 96.4 & IIIb \\
\hline $16 X-5,15-17$ & 560.95 & 3.9 & 27.5 & 68.6 & IIIb \\
\hline $16 \mathrm{X}-6,36-38$ & 562.66 & 0.8 & 25.4 & 73.8 & $\mathrm{IIIb}$ \\
\hline $16 \mathrm{X}-7,49-54$ & 563.79 & 0.3 & 8.3 & 91.4 & IIIb \\
\hline $17 X-2,103-106$ & 566.63 & 2.4 & 16.1 & 81.5 & $\mathrm{IIIb}$ \\
\hline $17 X-2,120-150$ & 566.80 & 3.2 & 22.8 & 74.0 & IIIb \\
\hline $17 X-4,23-27$ & 568.83 & 0.0 & 51.3 & 48.7 & IIIb \\
\hline $17 \mathrm{X}-5,0-40$ & 570.10 & 0.0 & 19.3 & 80.7 & $\mathrm{IIIb}$ \\
\hline $17 X-5,86-89$ & 570.96 & 0.1 & 11.5 & 88.3 & IIIb \\
\hline $17 \mathrm{X}-6,136-138$ & 572.96 & 4.7 & 13.3 & 82.0 & $\mathrm{IIIb}$ \\
\hline $18 \mathrm{X}-1,99-103$ & 574.29 & 0.0 & 34.4 & 65.6 & IIIb \\
\hline $18 \mathrm{X}-2,142-146$ & 576.22 & 0.0 & 32.4 & 67.6 & IIIb \\
\hline $18 \mathrm{X}-3,122-125$ & 577.52 & 1.8 & 10.9 & 87.2 & $\mathrm{IIIb}$ \\
\hline $18 \mathrm{X}-4,110-150$ & 578.90 & 0.2 & 27.9 & 71.9 & $\mathrm{IIIb}$ \\
\hline $18 \mathrm{X}-4,110-150$ & 578.90 & 1.2 & 15.9 & 82.9 & IIIb \\
\hline $18 \mathrm{X}-6,14-17$ & 580.94 & 1.3 & 5.5 & 93.1 & $\mathrm{IIIb}$ \\
\hline $19 X-2,22-26$ & 584.52 & 0.0 & 5.7 & 94.3 & IIIb \\
\hline $19 \mathrm{X}-3,40-42$ & 586.20 & 2.2 & 2.1 & 95.7 & IIIb \\
\hline $19 X-4,46-49$ & 587.76 & 2.5 & 3.0 & 94.5 & IIIb \\
\hline $19 X-4,110-150$ & 588.40 & 0.5 & 12.7 & 86.8 & IIIb \\
\hline $19 \times-5,36-39$ & 589.16 & 1.6 & 15.6 & 82.8 & $\mathrm{IIIb}$ \\
\hline $19 \mathrm{X}-6,26-30$ & 590.56 & 2.4 & 31.6 & 66.0 & IIIb \\
\hline $19 X-7,37-40$ & 592.17 & 2.3 & 12.3 & 85.4 & $\mathrm{IIIb}$ \\
\hline 48D-Packer & & 55.6 & 15.3 & 29.1 & \\
\hline
\end{tabular}

Notes: Determined using SediGraph. Lithologic units from Shipley, Ogawa, Blum, et al., 1995. 
Table 2. Site 949 textural data.

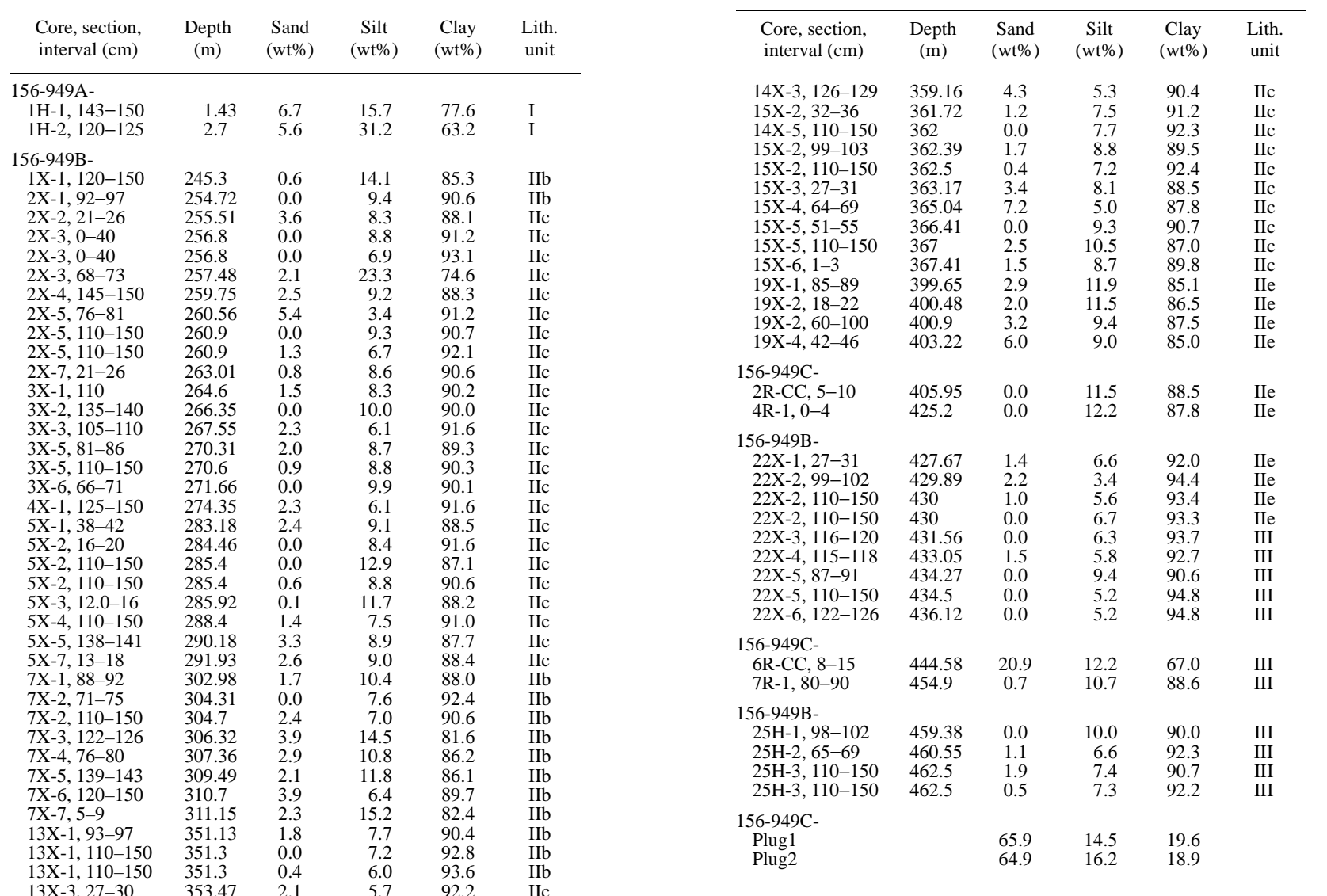

Notes: Determined using SediGraph. Lithologic units from Shipley, Ogawa, Blum, et $13 \mathrm{X}-3,27-30$

$14 \mathrm{X}-2,0-40$

$353.47 \quad 2.1$

$356.4 \quad 1.1$

al., 1995. 


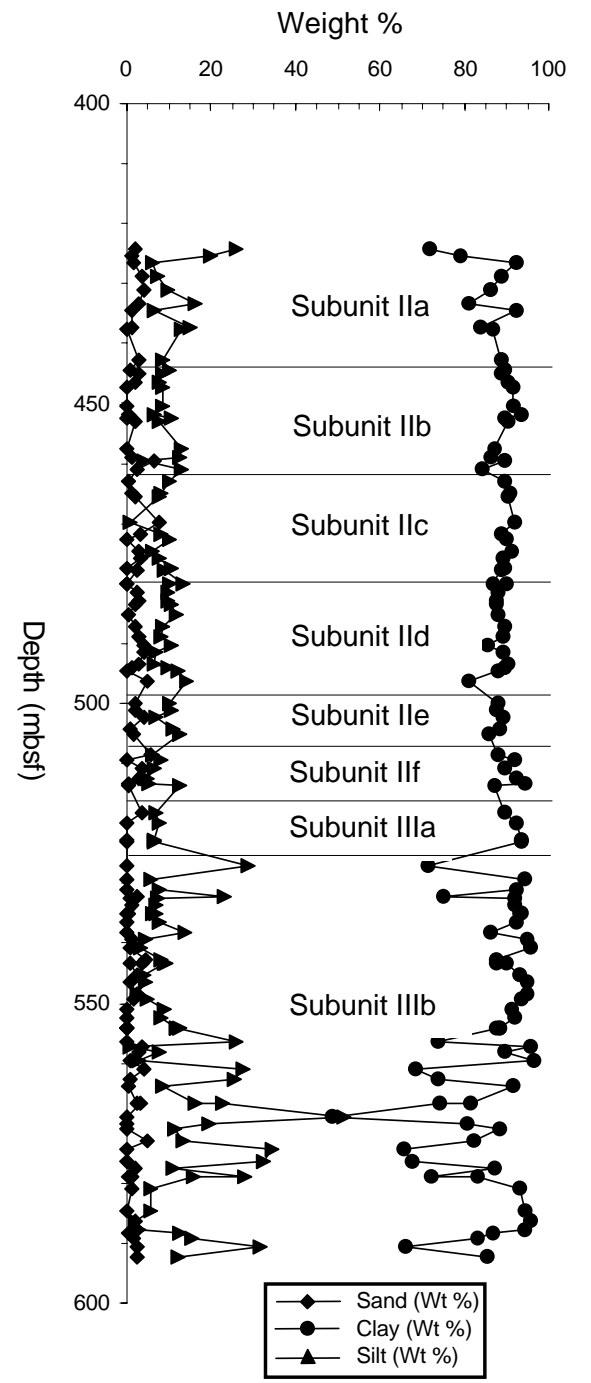

Figure 1. Sand, silt, and clay weight percentages vs. subbottom depth from lithologic Units II and III at Site 948.

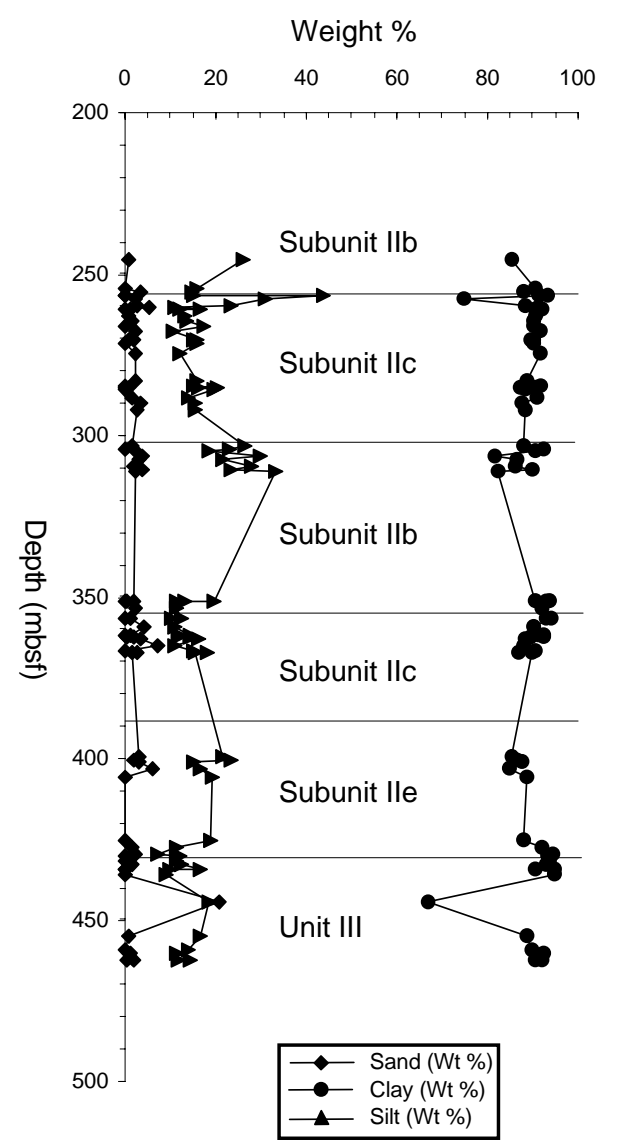

Figure 2. Sand, silt, and clay weight percentages vs. subbottom depth from lithologic Units II and III at Site 949. Large data gaps are because of poor core recovery. 